\title{
TINJAUAN ASPEK HUKUM KOPERASI (COOPERATIVE) \\ DAN UMKM (SMALL MEDIUM ENTERPRISES) \\ PADA NEGARA BELANDA
}

\author{
Manertiur Meilina Lubis \\ Pasca Sarjana Fakultas Hukum Universitas Indonesia \\ Linalubis99@gmail.com
}

\begin{abstract}
ABSTRAK
Penulisan ini dilator belakangi oleh kemajuan dan peningkatan pembangunan nasional pada umumnya dan pekermbangan kegiatan ekonomi pada khususnya yang menyebabkan pula berkembangnya dunia usaha dan perusahaan. Memerlukan adanya legalitas perusahaan yang merupakan sumber informasi resmi untuk semua pihak yang berkepentingan dan hal-hal yang menyangkut dunia usaha perusahaan yang didirikan. Mengingat bahwa banyaknya usaha/perusahaan seperti Koperasi dan UMKM. Dalam pendirian usaha harus memperhatikan aspek hukum, mulai dari perizinan usaha dan daftar perusahaan yang harus sesuai dengan ketentuan undang-undang dan atau peraturan-peraturan pelasanaannya, dan memuat hal-hal yang wajib didaftarkan oleh setiap perusahaan serta disahkan oleh pejabat berwenang dari kantor pendaftaran tersebut. Penulisan makalah ini bertujuan utnuk mengetahui bagaimana aspek hukum badan usaha Koperasi dan UMKM di suatu negara tertentu.
\end{abstract}

\section{Kata Kunci: Legalitas, Koperasi dan UMKM}

\begin{abstract}
This writing is grounded by the progress and improvement of national development in general and the development of economic activity in particular that causes also the development of business world and company. It requires company legality which is the official source of information for all interested parties and matters relating to the business world of the company that was founded. Given that there are many businesses / companies such as cooperatives and SME. In establishing a business, it must pay attention to legal aspects, starting from business licensing and a list of companies that must comply with the provisions of the law and / or its operational regulations, and contain matters that must be registered by each company and legalized by the authorized official of the registration office. . Writing this paper aims to find out how the legal aspects of cooperative and SME business entities in a particular country.
\end{abstract}

Keywords: Legality, Cooperatives and SME 


\section{PENDAHULUAN}

Pemerintah Belanda sangat menganjurkan masyarakat untuk lebih berwirausaha agar dapat menciptakan lapangan kerja baru yang lebih banyak untuk masyarakat lainnya, dalam rangka mendapatkan pengakuan (legalitas) tersebut. Haruslah mengetahui bagaiamana langkah-langkah yang harus diambil, legalitas dalam perusahaan atau badan usaha yang merupakan unsure yang sangat penting, karena legalitas perusahaan (Badan Usaha) dalam kegiatan bisnis adalah jati diri yang melegalkan atau menegaskan badan usaha agar nantinya dapat diakui oleh masyarakat. Dengan kata lain, legalitas perusahaan harus sah dalam undang-undang dan peraturan dimana perusahaan tersebut akan dilindungi dengan berbagai dokumen hingga sah di mata hukum.

Dalam suatu usaha faktor legalitas ini berwujud pada kepemelikan izin usaha yang dimiliki, dengan mempunya izin pendirian tersebut maka perusahaan atau badan usaha tidak ada yang perlu dikhawatirkan. Legalitas itu akan mendatangkan sejumlah manfaat bagi perusahaan. Begitu pentingnya legalitas perusahaan bagi setiap kegiatan usaha maka sebaiknya harus segera dipenuhi, karena bisnis kerap kali akan mengalami kegagalan karena terbentur akan berbagai permasalahan hukum atau tidak memperoleh izin pendirian. Oleh karena itu, sebelum pemikiran tentang usaha dilaksanakan secara mendalam terhadap aspek hukum harus dilakukan agar dikemudian hari usaha yang dilaksanakan tidak gagal karena terbentur permasalahan hukum dan perizinan .

Berdasarkan hal diatas, maka aspek hukum badan usaha koperasi dan UMKM (Usaha Mikro Kecil Menengah) di negara Belanda yang akan dianalisis lebih lanjut. Dimana, Sejarah kelahiran dan berkembangnnya koperasi di negara maju dan negara berkembang memang sangat diametral. Di negara maju koperasi lahir sebagai gerakan untuk melawan ketidakadilan pasar, oleh karena itu tumbuh dan berkembangnya koperasi berada dalam suasana persaingan pasar. Bahkan dengan kekuatannya itu koperasi meraih posisi tawar dan kedudukan penting dalam konstelasi 
kebijakan ekonomi termasuk dalam perundingan internasional. Peraturan perundangan yang mengatur koperasi tumbuh kemudian sebagai tuntutan masyarakat koperasi dalam rangka melindungi dirinya. ${ }^{1}$

Dinegara berkembang koperasi dirasa perlu dihadirkan dalam kerangka membangun institusi yang dapat menjadi mitra negara dalam menggerakan pembangunan untuk mencapai kesejahteraan masyarakat. Oleh karena itu, kesadaran antara kesamaan dan kemuliaan tujuan negara dan gerakan koperasi dalam memperjuangkan peningkatan kesejahteraan masyarakat yang ditonjolkan negara berkembang, baik oleh pemerintah kolonial maupun pemerintahan bangsa sendiri setelah kemerdekaan, berbagai peraturan perundangan yang mengatur koperasi dilahirkan dengan maksud mempercepat pengenalan koperasi dan memberikan arah bagi pengembangan koperasi serta dukungan/perlindungan yang diperlukan. ${ }^{2}$

Dalam konteks historis kita mengenal adanya dua sistem ekonomi ekstrem yaitu sistem kapitalisme dan sosialisme. Pada perkembangannya selanjutnya muncul sistem ekonomi campuran yang mencoba menggabungkan kedua sistem ekstrem tersebut. ${ }^{3}$ Sejarah koperasi memang tidak bisa dilepaskan hubungannya dengan perkembangan sosialisme yang merupakan antithesis dari kapitalisme yang berkembang di Eropa.Memburuknya kinerja kapitalisme yang ditandai dengan terjadinya depresi ekonomi dengan indikasi banyaknya pengangguran dan kelangkaan barang, mendorong muncuknya gerakan dari orang-orang yang tertindas ekonominya seperti kaum buruh untuk mewujudkan ide tentang koperasi.

Badan usaha UMKM juga memeliki peran penting dalam perekonomian Belanda. Karena dengan UKM ini telah dipromosikan dan dijadikan sebagai agenda utama pembangunan ekonomi Belanda. Memulihkan

\footnotetext{
${ }^{11}$ Hudiyanto, Koperasi: Ideologi dan Pengelolaannya, Proyek Peningkatan Penelitian Pendidikan Tinggi Direktorat Jenderal Pendidikan Tinggi Departemen Pendidikan Nasional.

2 Edy Suandi Hamid, Perekonomian Indonesia, (Jakarta: Pusat Penertbitan Universitas Terbuka,2006), hal.20.

${ }^{3}$ Ibid,hal.24.
} 
momentum untuk mendorong kegiatan pembuatan kebijakan UKM harus menjadi prioritas pemerintah, pembangunan sector tersebut telah terhambat oleh relative kurangnya perhatian selama periode pembentukan pemerintah yang panjang. Prioritas harus diberikan inisiatif tentang bantuan negara \& pengadaan publik. Secara khusus, pemerintah harus mendorong lebih banyak UKM untuk berpartisipasi lebih lagi.

Kehadiran UKM merupakan dasar bagi pertumbuhan banyak negara di dunia termasuk Belanda. Karena UKM memiliki tingkat fleksibilitas yang tinggi untuk merespon lebih cepat tuntutan pelanggan. UKM dapat secara efektif mengadopsi semua perubahan lingkungan dengan relevan. Oleh karena itu, saat ini posisi keberadaan UKM atau SME (Small Medium Enterprise) dimancanegara mendapat perhatian cukup besar oleh pemerintah negara, khususnya negara berkembang.

Salah satu tujuan pembanguan adalah untuk menciptakan tingkat Gross National Product yang setinggi-tingginya, namun hal ini tidak terlepas dari aspek hukum yang mengatur. Berdasarkan uraian diatas maka penulis akan mengkaji aspek hukum Koperasi dan UMKM di negara Belanda.

\section{METODE PENELITIAN}

Penelitian ini merupakan sebuah bentuk kegiatan ilmiah, dengan menggunakan metode penelitian jenis normatif yaitu yang mengacu kepada norma-norma hukum yang terdapat dalam peraturan perundangundangan sebagaimana idealnya suatu hal yang diatur didalam undangundang. ${ }^{4}$ Penelitian hukum normative merupakan penelitian kepuastakaan atau studi dokumen, yaitu penelitian dilakukan atau ditujukan pada peraturan-peraturan tertulis atau disebut juga dengan data sekunder.

${ }^{4}$ Peter Mahmud Marzuki, Penelitian Hukum, (Jakarta: Kencana Prenada Media Group,2005), hal.60. 


\section{HASIL PENELITIAN DAN PEMBAHASAN}

\section{Aspek Hukum Koperasi di Negara Belanda}

\section{a. Perkembangan Koperasi di Belanda}

Lahirnya koperasi sangat erat kaitannya dengan revolusi Industri Inggris yang terjadi pada pertengahan abad ke -18. Revolusi industri tersebut melahirkan tatanan ekonomi baru yang berbasis kapitalisme. Sistem ekonomi kapitalis hanya berpihak pada pemilik modal dan mengabaikan pihak lannya. Tak heran revolusi industri justru memperdalam kemeralatan dan kemiskinan bagi masyarakat ekonomi lemah. Dalam kemiskinan dan kemelaratan ini, lahirnya koperasi pertama di Inggris yang dengan dengan nama koperasi Rochdale di bawah pimpinan Charles Howart (tahun 1844). Melihat perkembangan usaha koperasi baik di sektor produksi maupun di sektor perdagangan, pimpinan CWS kemudian membuka perwakilan-perwakilan di luar negerti seperti New York, Kepenhagen, Hamburg, dan lain-lain.

Berkembangnya koperasi di negara maju (barat) dan negara berkembang memang sangat diametral. Di barat koperasi lahir sebagai gerakan untuk melawan ketidakadilan pasar, oleh karena itu tumbuh dan berkembang dalam suasana persaingan pasar. Bahkan dengan kekuatannya itu koperasi meraih posisi tawar dan kedudukan penting dalam konstelasi kebijakan ekonomi termasuk dalam perundingan internasional. Peraturan perundang-undangan yang mengatur koperasi tumbuh kemudian sebagai tuntutan masyarakat koperasi dalam rangka melindungi dirinya. Di negara berkembang koperasi dirasa perlu dihadirkan dalam kerangka membangun institusi yang dapat menjadi mitra negara dalam menggerakkan pembanguna untuk mencapai kesejahteraan masyarakat. Oleh karena itu kesadaran antara kesamaan dan kemuliaan tujuan negara dan gerakan koperasi dalam memperjuangkan peningkatan kesejahteraan masyarakat ditonjolkan di negara berkembang, baik oleh pemerintah kolonial maupun pemerintahan bangsa sendiri setelah kemerdekaan. Berbagai 
peraruean perundangan yang mengatur koperasi dilahirkan dengan maksud mempercepat pengenalan koperasi dan memberikan arah bagi pengembangan koperasi serta dukungan/perlindungan yang diperlukan. ${ }^{5}$

Di negara Belanda, orang mula-mula mendirikan koperasi konsumsi untuk menyediakan keperluan sehari-hari. Tetapi kemudian meluas dan muncul beberapa jenis atau nama koperasi. Di Rotterdam pada tahun 1860, persatuan buruh, Nederlandsch Werkman, mendirikan perkumpulan toko. Tetapi karena modalnya kecil, tempat tinggal buruh relatif tersebar, dan anggota kurang, perhatian dan kurang partisipasi pada toko akhirnya toko itu pun tidak dapat berkembang. Hal yang sama juga berlaku pada buruh di Amsterdam, yang pada tahun 1866, dibawah pimpinan N.G. Pierson mendirikan perkumpulan toko. Tidak kurang dari 2000 buruh menyatakan bersedia menjadi anggota. Tetapi pada waktu toko dibuka, jarang orang datang untuk melakukan pembelian. Dan akhirnya pada penghujung akhir tahun 1866 dibubarkan.

Pada tahun 1865 dibentuk komisi yang terdiri dari 10 orang, diantaranya Dr.S.Sarpathi dan N.G.Pierson, dengan tugas mempelajari masalah koperasi. Setelah itu berdirilah koperasi di Utrecht, Voorschoten, Leeuwaarden, Heerenveen dan Den Haag. Berawal dengan mengembangkan usaha simpan pinjam, kemudian merambah ke usaha konsumsi. Lambat laun kaum buruh menganggap betapa pentingnya koperasi bagi kesejahteraan buruh, dan kemudian organisasi buruh di negeri Belanda membahas secara khusus masalah perkoperasian tersebut. ${ }^{6}$ Di tahun 1973 di Utrecht diselenggarakan kongres, yang keputusannya antara lain menganjurkan agar kaum buruh beroperasi menurut cara orang-orang Rochdale.

5 Farah Nisrina, dkk, Cooperatives in West, Socialist, and Developing Countries, (Bandung: Universitas Komputer Indonesia,2016), hal. 10-11.

${ }^{6}$ Ibid,hal.20. 
Tahun 1876 pemerintah Belanda menetapkan Undang-Undang pertama pada tanggal 17 November 1876, staatsblad nomor 227. Undang-Undang ini kemudian diubah dengan Undang-Undang Koperasi, tanggal 28 Mei 1925, Staatsblad nomor 204.

\section{Pengertian Koperasi}

Koperasi memiliki beberapa arti, menurut asal dari kata "Koperasi" berasal dari bahasa latin yakni "coopere" yang dalam bahasa inggris disebut dengan "cooperation", atau Co-operatie dalam bahasa Belanda. "co" mengandung arti bersama dan "operation" artinya bekerja.Jadi, cooperation berarti bekerja sama. Dengan demikian, secara terminologi, koperasi yang mempunyai arti "kerja sama", atau mengandu makna kerja sama. Sedangkan Pengertian umum koperasi adalah suatu kumpulan orang-orang yang mempunyai tujuan sama, diikat dalam suatu organisasi bisnis yang berasaskan kekeluargaan dengan maksud mensejahterakan anggotanya. ${ }^{7}$

Definisi koperasi menurut ILO (International Labour Organization) adalah koperasi merupakan perkumpulan orang-orang, penggabungan orang-orang berdasarkan kesukarelaan, terdapat tujuan ekonomi yang ingin dicapai, koperasi berbentuk organisasi bisnis yang diawasi dan dikendalikan secara demokratis, terdapat kontribusi yang adil terhadap modal yang dibutuhkan, Anggota koperasi menerima resiko dan manfaar secara seimbang.

Definisi koperasi juga dijabarkan oleh P.J.V. Dooren yang mengatakan bahwa koperasi tidaklah hanya kumpulan orang-orang, akan tetapi dapat juga merupakan kumpulan dari badan-badan hukum (coorporate) ${ }^{8}$

Richard Kohl dan Abrahamson menjelaskan koperasi sebagai badan usaha dengan kepemilikan dan pemakai jasa merupakan anggota

\footnotetext{
${ }^{7}$ Uang Teman , Pengertian Koperasi Menurut Para Ahli Dan Lembaga Penelitian, 30 Agustus 2017, hal. 1-2.

${ }^{8}$ Sugi Priharto, Pengertian Koperasi, 2 Agustus 2019, hal. 1.
} 
dari koperasi itu sendiri serta pengawasan terhadap badan usaha tersebut harus dilakukan oleh yang menggunakan jasa dan pelayanannya. ${ }^{9}$

Dari berbagai pengertian koperasi di atas, dapat ditarik kesimpulan bahwa koperasi merupakan sebuah organisasi berasaskan kekeluargaan yang tujuannya membantu mendongkrak perekonomian rakyat. Peran koperasi di dalam masyarakat yang baru merintis usaha. Sebagai salah satu jalan yang disediakan untuk kemajuan kualitas kehidupan masyarakat, sudah sewajarnya kita mendukung perkembangan koperasi dan mengawal pelayanannya.

\section{b. Aspek hukum koperasi negara Belanda}

1. Aspek Regulasi tentang Koperasi

Staatsblad No. 431 Tahun 1915 (Verodening de Coperative Verenigning) koperasi dapat tumbuh dan berkembang dengan baik dalam kondisi dan situasi dari anggota masyarakat dimana koperasi itu berdiri dan mendapatkan tekanan - tekanan ekonomi di dalam kehidupan mereka. Dengan adanya tekanan tersebut orang-orang menjadi berusaha mencari jalan kelaur dengan cara bekerja sama mempersatukan potensi-potensi yang mereka miliki ke dalam organisasi. Peraturan untuk perkumpulan operasi Hindia Belanda tersebut tidak berlaku secara khusus untuk bangsa eropa, Timur asing aja, melainkan diberlaukan kepada pribumi.Belanda yang khawatir koperasi dijadikan tempat pusat perlawanan kemudian mengeluarkan aturan yang berisi antara lain: ${ }^{10}$

1. Untuk mendirikan sebuah koperasi maka pengurus harus membayar minimal 50 Gulden

2. Sistem usaha koperasi yang dibuat harus menyerupai sistem koperasi yang sudah diterapkam di Eropa

3. Pendirian koperasi tersebut harus mendapat persetujuan dari Gubernur Jenderal Hindia

${ }^{9}$ Ibid,

${ }^{10}$ Arifin, Sitio dan Tamba Halomoan, Koperasi, Teori dan Praktik, (Jakarta: Erlangga, 2001), hal.41. 
4. Proposal pengajuan pendirian koperasi harus menggunakan bahasa Belanda.

Adanya aturan tersebut menyebabkan koperasi yang ada saat itu berjatuhan karena tidak mendapatkan izin koperasi dari Belanda. Namun, setelah para tokoh Indonesia mengajukan protes maka pada tahun 1927 atas prakarsa Dr.H.J.Boeke, Belanda mengeluarkan Undang-Undang No.91 Tahun 1927 yang isinya lebih ringan dari Undang-Undang Nomor 431 Tahun 1915, peraturan pendirian koperasi menjadi lebih mudah sehingga mendorong masyrakat mendirikan koperasi. The Studi Club 1928, sebuah organisasi kaum intelektual yang ikut berperan dalam mendorong berdirinya koperasi di negara Indonesia. UndangUndang Nomor 91 Tahun 1927 tersebut antara lain berisi:

1. Untuk dapat Mendirikan Koperasi Maka Pengurus hanya dikenakan biaya sebesar 3 gulden untuk materai.

2. Proposal pengajuan pendirian koperasi dapat menggunakan baasa Daerah

3. Hukum dagang diberlakukan sesuai daerah masing-masing

4. Perizinan bisa dilakukan didaerah setempat.

Adanya Undang-Undang Nomor 91 Tahun 1927 memberi angin segar bagi perkembangan koperasi. Namun, kondisi ini tidak berlangsung lama karena pada tahun 1933 Belanda kembali mengeluarkan undang-undang yang isinya hamper sama dengan Undang-Undang Nomor 431 sehingga mematikan usaha koperasi untuk yang kedua kalinya.

Peraturan yang terkait dengan koperasi sebelumnya: ${ }^{11}$

a. Stb. 431 tahun 1915 (Verondering Op De Cooperative Verenigingen).

11 Trian Sofiana,Konstruksi Norma Hukum Koperasi Syariah Dalam Kerangka Sistem Hukum Koperasi Nasional, Jurnal Hukum Islam (JHI), hal.40. 
Merupakan regulasi pertama yang berlaku bagi semua golongan penduduk (Pasal 131 IS). Sistem yang diberlakukan di Belanda ternyata menyusahkan penduduk golongan III yakni Pribumi. Mereka dalam mendirikan badan usaha koperasi harus memiliki prasyarat mulai dari Akta Notaris, akta pendirian berbahasa Belanda, materai, hingga pengumuman di surat kabar Javasche Courant. Biaya yang dikeluarkan oleh pelaku usaha yang ingin membuat koperasi pada saat itu sangatlah besar, sehingga Verondering $O p D e$ Cooperative Verenigingen dirasa tidak memberikan manfaat dan banyak ditentang.

b. Staatsblad No. 91 Tahun 1927 (Regeling Inlandsche Cooperatieve Verenigingen )

Pada tanggal 10 Juni 1920 khusus berlaku untuk orangorang Indonesia dibentuklah Cooperatieve Commissie yang dipimpin oleh Prof. H.J. Boee. Pada saat politik balas budi Belanda baru saja didengungkan, perjuangan para nasionalis berhasil dengan keluarnya "Regeling Inlandsche Cooperatieve Verenigingen". Akhirnya, penerapannya Verordening op de Cooperatieve Verenigingen diperuntukan bagi penduduk golongan I ( Eropa) dan golongan II (Timur Asing), sedangkan Regeling Inlandsche Cooperatieve Verenigingen hanya untuk golongan III ( Pribumi) saja. Peraturan Koperasi ini tunduk pada Hukum Adat dan bukan pada BW( Hukum Perdata Belanada). Desakan liberalistik dari pasar tanah air atas bentukan Belanda pada saat itu membuat kemudahan demi kemudahan yang ditawarkan oleh Regeling Inlandsche Cooperatieve Verenigingen tidak berarti dan masih saja membuat koperasi di Indonesia sulit berkembang.

Dalam perkumpulan -perkumpulan koperasi Bumiputera Lembaran Negara 1927 Nomor 91. Dalam peraturan tersebut 
untuk pendirian koperasi dipermudah. Pengaturan yang memudahkan antara lain pasal 3, Pasal 5, Pasal 7 ayat (1) sampai dengan ayat (5) dan pasal 11. Pada pasal 5 peraturan koperasi tahun 1927 tentang yang mengatur akta pendirian koperasi lebih sederahana dan lebih mudah dibandingkan dengan pengaturan sebelumnya. Dalam pasal ini diberikan pilihan dalam penggunaan bahasa yang digunakan untuk membuat akta yaitu bahasa daerah, bahasa melayu atau bahasa Belanda. $^{12}$

Selain penggunaan bahasa, proses mengajukan akta pendirian kepada pemerintahan untuk memperoleh status badan hukum juga dipermudah. Dalam proses pengajuan akta pendirian koperasi untuk memperoleh badan hukum pada pengaturan tersebut menjadi lebih sederhana. Akta pendirian tidak lagi menggunakan akta dari Notaris, tidak memerlukan izin dari Gubernur Jenderal. Akta cukup diajukan kepada penasehat untuk urusan perkreditan rakyat koperasi. Selain itu pendirian koperasi juga tidak perlu diumumkan dalam surat kabar. Kemudahan yang paling penting adalah semua proses dalam pendaftaran, penyerahan dan pengumuman tidak dipungut biaya. Hal ini yang demikian tentu akan sangat membantu koperasi. Untuk mendirikan koperasi jadi hemat dalam biaya-biaya. ${ }^{13}$

Pengaturan lain yang memberikan kemudahan terakhir yang dapat ditemukan adalah pengaturan prinsip keterbukaan keanggotaan koperasi. Masuk dan keluarnya anggota cukup dibuktikan oleh pencatatan di dalam daftar. Dengan demikian, tidak lagi diperlukan adanya pihak ketiga, dan tidak pula pejabat maupun notaris yang membuat surat resmi sebagai

12 Sularso dan Damanik, Peraturan Perundang-undangan Koperasi di Indonesia, (Jakarta:Dwi Segara, 1982), hal.11.

13 Ibid, hal.12. 
anggota. Akses masyarakat untuk berperan serta dalam membangun koperasi menjadi semakin terbuka dan semakin mudah. Kemudahan lain diberikan sebagai tindak lanjut dari pengaturan tersebut Cooperatie Dienst (Jawatan Koperasi) pada tahun 1930 di bawah Department van Binnenlandshe Bestuur (Departemen Dalam Negeri) dan pada Tahun 1932 menerbitkan Surat Keputusan Pemerintah Nomor 29 yang dimuat dalam Staatsablad Nomor 634 Tahun 1932, yang menetapkan bahwa koperasi yang dibentuk berdasarkan Staatsblad Tahun 1927 Nomor 91, bebas pajak selama 10 tahun semenjak didirikan. ${ }^{14}$

Konsep tersebut dikembangkan berdasar kan realitas adanya dua sistem yang sosial berbeda antara pribumi dengan non pribumi. Jika perbedaan tidak diakomodir maka akan menim bulkan benturan dalam masyarakat. Oleh karenanya secara pengaturan, jika keduanya tidak dapat disatukan maka harus diberikan dua aturan yang berbeda untuk masing-masing. Dualisme pengaturan koperasi ini berlanjut saat Verordening op De Cooperative Verenigingen Statsblad 431 Tahun 1915 diganti Algemeene Regeling op de Cooperative Vereeniiging Staatsblad 103 Tahun 1933. Penggantian tersebut menyesuaikan dengan UU Koperasi belanda yang baru, yang dibentuk pada tahun $1925 .^{15}$

c. Staatsblad No.108 Tahun 1933 pada tanggal 28 Mei 1925 Algemene Regeling op de Cooperatieve Verenigingen )

Peraturan mengenai koperasi Belanda yaitu Regeling Der Cooperatieve Verenigingen Stb. 227 tahun 1876 diganti dengan Regeleing Der Cooperatieve Verenigingen Stb. 204 Tahun 1925. Oleh karena itu, untuk menyesuaikan perubahan tersebut pada tanggal 1 maret 1933 diganti dengan Algeme Regeling Op

${ }^{14}$ Lincolyn Arsyad, Ekonomi Pembangun, (Yogyakarta: STIE YKPN, 2008), hal.208. 
De Cooperative Vernignigen Stb. 108 Tahun 1933, peraturan ini tunduk pada hukum barat dimana terdapat dualisme peraturan koperasi. Secara umum dikatakan bahwa isi ketentuan-ketentuan yang ada di dalamnya tidak berbeda dengan isi ketentuan-ketentuan yang ada di dalam Stb. 431 tahun 1915 (Verondering Op De Cooperative Verenigingen). Algemene Regeling op de Cooperatieve Verenigingen, merupakan perubahan dari Verordening op de Cooperatieve Verenigingen yang berlaku bagi penduduk golongan I, II dan III, namun di sisi lain Regeling Inlandsche Cooperatieve Verenigingen masih diberlakukan untuk Gol. III(pribumi). Pada masa ini, Departemen Ekonomi atas anjuran dari Jawatan Koperasi mendirikan gabungan dari pusat-pusat koperasi di Hindia Belanda yang dinamakan Moeder Centrale. Sedangkan usaha menyuntikan dana segar sebesar f-25.000.000 untuk koperasi, menjadi gagal dengan keluarnya Ordonantie op Inlandsche Maatshapji op Aandeelen yang memudahkan pelaku usaha berkembang dengan menggunakan Maskapai Andil dan bukan Koperasi yang dicanangkan pada saat adanya Algemene Regeling op de Cooperatieve Verenigingen.

d. Staatsblad No.179 Tahun 1949 ( Regeling Cooperatieve Verenigingen)

Dikeluarkan oleh Pemerintah federal Belanda. Regulasi yang pertama kali dicetuskan sejak kemerdekaan Indonesia ini, muncul karena adanya krisis yang berkepanjangan mulai dari agresi militer Belanda, hingga pemberontakan PKI. Regulasi ini mengubah definisi koperasi dengan menambahkan unsur syarat pendiriannya. Pada saat regulasi ini berlaku, banyak hal yang terjadi mulai dengan adanya Kongres Pertama Koperasi seluruh Indonesia, yang hari 12 Juli 1947 dijadikan sebagai, "Hari Koperasi”, adanya Bank Koperasi Provinsi, hingga pembekuan 
oleh Menteri Kehakiman atas Algemene Regeling op de Cooperatieve Verenigingen.

Ketentuan-ketentuan mengenai pendirian koperasi ditentukan sebagai berikut : ${ }^{16}$

a. Dibuat dalam akta notaris

b. Akta pendirian dalam bahasa Belanda

c. Bea Materai 50 Gulden

d. Mendapatkan surat persetujuan gubernur Jenderal Batavia

e. Akta pendirian didaftarkan di daerah hukum kedudukan koperasi

f. Hak tanah menurut hukum Belanda

g. Mengumumkan dalam berita Negara

h. Mengumumkan dalam surat kabar berbahasa melayu

i. Mengumumkan dalam surat kabar Javasche Courant

Dalam akta pendirian perkumpulan koperasi tersebut harus dimuat:

a. Nama perkumpulan koperasi

b. Data pribadi para pendiri

c. Ketentuan sejauh mana masing-masing anggota bertangung jawab secara pribadi dalam perkumpulan koperasi

d. Pengaturan tentang pengurusan dan kepengawasan

e. Jangka waktu berdiri (tidak boleh lebih dari 30 tahun meskipun dapat diperpanjang)

f. Tanggal pembukuan

g. Syarat Keanggotaan

Ketentuan-ketentuan tersebut dirasakan oleh perggerak koperasi nasional sebagai untuk menghambat koperasi di Belanda karena pemerintah khawatir terhadap keberadaan koperasi yang dapat dijadikan sebagai wadah dan alat perjuangangan melawan

16 Ansika Prasetya, Sejarah Perkembangan Koperasi Di Indonesia, Tanggal 11 Desember 2013, hal. 30. 
kekuasaanya. Oleh karena itu peraturan tersebut tidak diikuti oleh rakyat Belanda dan mendapatkan reaksi keras dari kaum pergerakan nasional dan pergerakan koperasi untuk menggantikan peraturan tersebut, sehingga dibuatlah peraturan baru yaiu Regeling Inlannddsche Cooperative Verenigingen (Staatsblad No. 91 Tahun 1927) yang mudah diikuti oleh orang asli Hindia Belanda yang hendak mendirikan perkumpulan koperasi. ${ }^{17}$

\section{Pendirian dan Manajemen Koperasi}

Secara praktis ada dua bentuk asosiasi di Belanda, tergantung pada kapasitas hukum mereka, yaitu : ${ }^{18}$

1. Asosiasi Kapasitas penuh

Ketika membangun sebuah asosiaso dengan kapasitas peuh (volledige rechtsbevoegdheid), secara teoritis tidak membawa tanggung jawab pribadi atas utangnya dan memerluka notaris Latin untuk menyiapkan akta yang menyatakan pendirian asosiasi. Asosiasi dengan kapasitas penuh ini harus terdaftar di Register Perdagangan (Handelsregister) di kamar dagang (kamer van koophandel). Memiliki tugas dan hak anggotanya publik, misalnya mereka dapat meminjam uang dan mewarisi dan memiliki properti terdaftar, organisasi subsisi biasanya mensyaratkan asosiasi bersubsidi untuk memiliki kapasitas penuh dalam istilah hukum.

2. Asosiasi kapasitas terbatas

Sebuah asosiasi yang dibentuk tanpa notaris Latin hanya memiliki kapasitas terbatas dalam istilah hukum (beperkte rechtbevoegdheid) dan pemiliknya membawa tanggung pribadi untuk semua kewajibannya. Kewajiban ini dapat dibatasi dengan mendaftarkan asosiasi di National Commercial

\footnotetext{
${ }^{17}$ Wikipedia Bahasa Indonesia, Koperasi, https://id.wikipedia.org/wiki/Koperasi , hal.1.

${ }^{18}$ Intercompany Solutions,Daftarkan Asosiasi Di Belanda, 13 April 2018, hal. 1.
} 
Registry.Asosiasi terbatas diizinkan memiliki properti terdaftar, misalnya real estate.

Kedua asosiasi kapasitas terbatas dan asosiasi kapasitas penuh dapat digunakan untuk membentuk koperasi. Koperasi dapat mencakup dua atau lebih anggota. Entitas tersebut dikendalikan oleh Algemene Ledenvergadering atau General Members Meeting (GMM). GMM menunjuk dewan manajamen untuk menangani urusan koperasi. Harus menggunakan jasa notaris Latin untuk menyiapkan akta pendirian entitas dan mendaftarkannya di National Commercial Registry (Handelsregister). Memerlukan notaris Latin untuk menyiapkan akta yang menyatakan pendirian koperasi dan angggarannya termasuk:

- Nama dan alamat

- Obyektif (bagi hasil di antara mitra tidak dianggap obyektif )

- Persyaratan untuk memasukkan anggota

- Prosedur untuk mengadakan Rapat Anggota Umum

- Prosedur untuk pengangkatan dan penghapusan anggota komite

- Alokasi surplus pasca pembubaran

Jika memutuskan untuk mengubah hal-hal diatas, perlu menyewa notaris Latin untuk memperbarui akta pendirian koperasi. Koperasi memilki peraturan internal yang melengkapi undangundang. Dengan memperhatikan urusan sehari-hari yang praktis, aturan internal ini tidak perlu diaktakan

Diwajibkan mendaftarkan koperasi di register dagang Belanda untuk mendapatkan kapasitas hukum penuh, membawa tanggung jawab pribadi sampai tanggal pendaftaran. Biasanya, notaris Latin yang berurusan dengan pembentukan juga akan menyelesaikan pendaftaran tetapi disarankan untuk meminta 
konfirmasi dan harus melaporkan setiap perubahan dalam daftar anggota komiter ke kamar dagang dalam delapan hari.

Para anggota koperasi menutup biaya pengaturan dan fungsinya. Setiap keuntungan yang dihasilkan di distribusikan sehubungan dengan saham anggota dalam pergantian umum kolektif. Para anggota bebas untuk menegosiasikan pengaturan khusus sehubungan dengan pembagian kepentingan. Anggota biasa dan anggota dewan dari koperasi yang mengatur diri sendiri memiliki hubungan kerja fiktif yang efektif (fiktif diensbetrekking) dengan entitas. Dalam hal ini, pemotongan gaji sama dengan orang yang bekerja secara reguler.

Pembubaran koperasi adalah ketika anggota rapat suara mendukung, tidak ada anggota yang tersisa atau kebangkrutan dinyatakan prosedur dan aturan pembubaran dituangkan dalam undang-undang.

\section{Kewajiban}

Kolektif bertanggung jawab dalam kapasitasnya sebagai entitas, tetapi jika anggotanya berencana membubarkannya pada saat memiliki hutang, semuanya memiliki bagian yang sama. Namun, kewajiban dapat dikecualikan dengan mendirikan koperasi tanggung jawab terbatas (BA atau beperkte aansprakelijkheid) atau koperasi kewajiban dikecualikan (UA atau uitgesloten aansprakelijkheidcooperative). Dalam koperasi pengusaha, para mitra yang bekerja sama dalam proyek membawa tanggung jawab atas hasil mereka. ${ }^{19}$

$$
\text { Koperasi membayar pajak koperasi }
$$
(vennootschapsbelasting) sehubungan dengan keuntungan koperasi. Anggota individu berhutang pajak penghasilan (inkomstenbelasting) sehubungan dengan pendapatan yang mereka

${ }^{19} \mathrm{Ibid}$, hal.2. 
dapatkan melalui koperasi. Koperasi diminta untuk menyiapkan dan mempublikasikan laporan keuangan dan laporan tahunan.

\section{Keadaan Koperasi Belanda}

Di Belanda koperasi sangat maju, Belanda juga punya banyak koperasi yang berkicimpung di sektor pertanian yang masuk 20 koperasi pertanian terbesar di UE, yakni Campina Melkunie (produk-produk susu), Cabeco Handelsrand (input dan produksi pertanian), Friesland Dairy Foods (Produk-produk susu), Coberco (Produk-produk susu), Demeco (daging), dan Greenary/VTN (buah-buahan dan sayur-sayuran). Di negara-negara Eropa Timur, koperasi juga sangat maju. Misalnya, di Hongaria, koperasi-koperasi konsumen bertaanggung jawab terhadap 14,4\% dari makanan nasional dan penjualan-penjualan eceran umum pada tahun 2004. Di Polandia, koperasi-koperasi susu bertanggung jawab untuk $75 \%$ dari produksi susu di dalam negeri. Di slovenia, koperasi-koperasi pertanian bertanggung jawab untuk $72 \%$ dari produksi susu, $79 \%$ dari sapi, $45 \%$ dari gandum, dan $77 \%$ dari produksi kentang, Di Slovakia, terdapat lebih dari 700 koperasi yang mengerjakan hampir 75 ribu orang. ${ }^{20}$

Kita dapat melihat bahwa negara maju seperti Belanda masih mengandalkan koperasi untuk menyejahterakan masyarakatnya agar negaranya tetap maju. Sudah banyak negara berkembang yang juga akhirnya berhasil dalam menjalankan koperasi untuk mendorong pertumbuhan ekonomi masyarakat. Karena kesejahteraan seluruh rakyat, suatu bangsa akan hidup tentram dan adil serta tidak ada lagi kesenjangan sosial.

\section{Jenis-Jenis Koperasi}

${ }^{20}$ Anita Melania,Koperasi Ekonomi, 19 Oktober 2019, hal.1. 
Koperasi adalah asosiaasi yang menyelesaikan kontrak tertentu dengan para anggotannya dan atas nama mereka. Dua jenis koperasi adalah sebagai berikut: ${ }^{21}$

a. Koperasi Bisnis (bedrijfscooperatie)

Koperasi jenis ini adalah kerja kolektif untuk mendukung kepentingan anggota di bidang tertentu misalnya iklan atau pengadaan. Contoh Belanda yang populer dari koperasi semacam ini adalah Friesland Campina, ini adalah koperasi besar yang menyatukan para peternak sapi perah dimana setiap anggota berkontribusi terhadap keuntungan kolektif.

b. Koperasi Pengusaha (ondernemerscooperatie)

Koperasi jenis ini memiliki anggota yang bekerja secara mandiri dan dapat memutuskan untuk bekerja sama dalam proyek tertentu. Bentuk entitas ini cocok untuk orang-orang yang berwiraswasta dan tidak memilki karyawan sendiri (zzp'er atau zelfstandige zonder personeel). Koperasi pengusaha memungkinkan anggotanya untuk bekerja sama dalam proyek atau tugas yang akan terlalu besar untuk mereka selesaikan sendiri.

Pelanggan juga mendapat keuntungan dari situasi ini dengan memiliki satu orang penghubung dan lebih pasti lagi bahwa tenggat waktu proyek mereka akan dipenuhi. Menjadi catatan, bahwa semua peserta dalam proyek-proyek umum yang bekerja dalam kapasitas alami (tidak hukum) orang perlu memilki klien lain diluar proyek. Untuk dipertimbangkan sebagai pengusaha untuk tujaun pengumpulan pajak penghasilan (ondernemer voor de inkomstenbelasting).

${ }^{21}$ Intercompany Solutions,Membentuk Koperasi Di Belanda, April 2018, hal. 1. 
Perbedaan ini penting untuk Bea dan Administrasi Pajak (belastingdienst). Semua Anggota koperasi memiliki hak untuk memilih dan bebas untuk meninggalkan atau memasuki kolektif, selama hal ini tidak membahayakan eksistensi jangka pangjangnya. Koperasi pengusaha cocok untuk proyek kolaboratif jangan pendek atau skala kecil.

\section{Permodalan Koperasi}

Koperasi sebagai bentuk badan usaha tentunya dalam melakukan kegiatan usahanya tidak terlepas dari masalah permodalan. Modal koperasi penting karena dengan adanya modal yang cukup maka koperasi akan mampu untuk bersaing dengan usaha-usaha lain diluar koperasi. ${ }^{22}$ Modal sebagaimana diketaahui adalah merupakan salah satu faktor produksi yang sangat penting, tetapi hingga sekarang diantara para ahli belum terdapat kesamaan pendapat tentang apa yang disebut dnegan modal itu.

Adam Smith salah seorang pelopor aliran klasih menulis buku yang berjudul "The Wealth of Nations" (1976), mengartikan modal sebagai bagian dari nilai kekayaan yang dapat mendatangkan penghasilan. Dalam perkembangannya, pengertian modal mengarah kepada sifat non fisik, dalam arti ditekankan kepada nilai, daya beli atau kekuasaan memakai atau menggunakan yang terkandung dalam barang modal.

Ada beberapa prinsip yang harus dipatuhi oleh koperasi dalam kaitannya dengan permodalan, yaitu sebagai berikut: ${ }^{23}$

- Pengendalian dan pengelolaan koperasi harus tetap berada ditangan anggota dan tidak perlu dikaitkan dengan jumlah

${ }^{22}$ Subandi, Ekonomi Koperasi,(Bandung: Alfabeta,2014), hal.81.

23 Muhammad Firdaus dan Agus Edhi Susanto, Perkoperasian Sejarah, Teori dan Praktek, (Bogor: Ghalia Indonesia, 2004), hal. 70-71. 
modal yang dapat ditanam oleh seseorang anggota dalam koperasi dan berlaku ketentuan suatu anggota satu suara.

- Modal harus dimanfaatkan untuk usaha-usaha yang bermanfaat dan meningkatkan kesejahteraan bagi anggota.

- Kepada modal hanya diberikan balas jasa yang terbatas

- Koperasi pada dasarnya memerlukan modal yang cukup untuk membiayai usahanya secara efisien

- Usaha-usaha dari koperasi harus dapat membantu pembentukan modal baru. Hal ini bisa dilakukan dengan menahan sebagian dari keuntungan/sisa hasil usaha (SHU) dan tidak membagikan semua kepada anggota. Misalnya melihat perusahaan-perusahaan di Amerika Serikat (AS) pada umumnya menahan lebih dari separuh dari keuntungan ini (setelah dikurangi pajak) untuk ditanamkan kembalu dalam usaha-usaha. Pembiayaan usaha koperasi dengan menggunakan modal yang diperoleh secara demikian ini, akan meringankan beban biaya modal.

- Kepada saham koperasi tidak bisa diberikan suatu premi diatas nilai nominalnya, meski seandainya nilai bukunya bisa bertambah.

\section{Konsep Koperasi}

Koperasi adalah organisasi swasta, yang dibentuk sukarela oleh orang-orang yang mempunyai kesamaan kepentingan, dengan maksud mengurusi kepentingan maupun perusahaan koperasi. Persamaan kepentingan tersebut berasal dari perorangan atau kelompok. Kepentingan bersama suatu kelompok keluarga atau kelompok kerabat dapat diarahkan untuk membentuk atau masuk menjadi anggota koperasi. ${ }^{24}$

\footnotetext{
${ }^{24}$ Farah Nisrina, Op.Cit, ,hal. 12.
} 


\section{Unsur-Unsur Koperasi ${ }^{25}$}

- Keinginan individu dapat dipuaskan dengan cara bekerjasama antar sesama anggota dengan saling membantu dan saling menguntungkan.

- Setiap individu dengan tujuan yang sama dapat berpartisipasi untuk mendapatkan keuntungan dan menanggu risiko bersama.

- Hasil berupa surplus/keuntungan di distribusikan kepada anggota sesuai dengan metode yang telah disepakati.

- Keuntungan yang belum di distribusikan akan dimasukkan sebagai caadangan koperasi.

\section{Aspek Hukum UMKM (Small Medium Enterprises) Belanda}

Belanda mendifinisikan UKM secara terpisah, dimana untuk usaha dilakukan oleh 10-50 orang dinamakan usaha kecil dan yang disebut sebagai usaha menengah adalah usaha yang dilakukan lebih dari 50 orang. Sedangkan untuk usaha mikro didefinisikan sebagai usaha yang dilakukan kurang dari 10 orang. ${ }^{26}$ Pengetahuan memainkan peran penting dalam menentukan kemampuan inovasiperusahaan dan dalam meningkatkan kualitas kehidupan kerja para pekerja.Pengetahuan dalam UKM dikelola secara berbeda. Pada dasarnya, pengetahuanlebih mungkin dibuat, dibagi, ditranfer, dan diterapkan melalui mekanisme diUKM. March (1991) menunjukkan bahwa ada dua mode yang berbeda secarafundamental dari inovasi, yaitu eksplorasi dan eksploitasi. Eksploitasi inovasidibangun di atas atau memperluas pengetahuan yang ada dari perusahaan,sedangkan eksplorasi inovasi membutuhkan pengetahuan dan kemampuan yangbaru untuk perusahaan. Perbedaan ini mungkin menunjukan daya serap bervariasidalam fungsi atau kepentingan untuk mencapai kedua jenis perilaku inovasi. Studiyang dilakukan oleh Zhou, dkk. (2007) pada UKM di belanda menunjukkan bahwa UKM berinovasi dengan cara yang berbeda.

${ }^{25}$ Farah Nisrina Op.Cit, ,hal. 12.

26 Ysabel Nauwelaerts dan Iris Hollaender, Innovation Management of SMEs in The CreativeSector in Flanders and The Netherlands, Vol.6,Iss.3,hal.140-153. 
Kecenderungan UKM memperoleh pengetahuan melalui ikatan sosial dan komunikasi dengan sumber daya eksternal, seperti universitas, konsorsium dan pemerintah. Oleh karena itu, pembuat kebijakan yang ingin merangsang perilaku inovasi UKM mungkin ingin menilai lingkungan eksternal di daerah tertentu atau suatu bangsa.

Penggambaran tradisional UKM dilakukan di tingkat perusahaan. Perusahaan kecil mempekerjakan kurang dari 50 karyawan dan perusahaan menengah mempekerjakan antara 50 dan 250 karyawan. Namun, ini menyiratkan bahwa di bawah definisi ini usaha kecil yang merupakan bagian dari perusahaan yang lebih besar (nasional atau internasional) kelompok perusahaan juga dianggap UKM. Pertimbangkan pusat distribusi yang besar pabrikan mobil asing mempekerjakan 50 orang secara lokal, tetapi mempekerjakan ribuan orang di seluruh dunia. Dari Perspektif kebijakan mempertimbangkan perusahaan ini sebagai UKM kurang diminati, karena kebijakan khusus UKM penargetan umumnya tidak dikembangkan dengan mempertimbangkan jenis usaha ini. Untuk mengurangi in masalah, kami mengandalkan versi modifikasi dari definisi UKM yang diusulkan oleh UE dalam rangka perancangan dan evaluasi kebijakan UKM. $^{27}$

Definisi yang dimodifikasi ini menggambarkan UKM menggunakan dua dimensi dari grup perusahaan (domestik): ukuran dan kebangsaan kepemilikan. Perusahaan harus bersama-sama, pada tingkat agregat nasional tertinggi (grup perusahaan), memiliki kurang dari 250 karyawan untuk dianggap sebagai UKM. Sebagai tambahan perusahaan yang lembaga pengendali utamanya selalu berada di luar Belanda dianggap sebagai bagian dari perusahaan multinasional besar (MNE). Dalam penilaian empiris dari Berbagai penggambaran UKM, Lemmers (2014) menunjukkan bahwa dari segi perdagangan dampak penerapannya definisi UKM yang dimodifikasi relatif terhadap definisi tradisional UKM

27 European Commission, What is an SME?, Accessed 07 December 2020 at http://ec.europa.eu/growth/smes/business-friendly-environment/sme-definition_en. 
adalah besar. Sebagai contoh, nilai impor dan ekspor yang diberikan kepada UKM menjadi lebih dari setengahnya bila semakin ketat definisi UE yang dimodifikasi diterapkan.

Perusahaan ditugaskan ke industri tertentu dengan menggunakan industri utama dari kegiatan perusahaan seperti yang tercantum dalam GBR. Pada tingkat yang paling detil, SUT dan IOT yang diperluas membedakan 128 industri. Kami membedakan lima kelas ukuran:

1. Perusahaan kecil yang mempekerjakan paling banyak 50 karyawan, bukan bagian dari perusahaan domestik besar kelompok dan bukan milik asing;

2. Perusahaan menengah yang mempekerjakan antara 50 dan 250 karyawan, bukan sebagian besar kelompok perusahaan dalam negeri dan bukan milik asing;

3. Usaha kecil atau menengah yang terkait dengan kelompok usaha domestik besar dan / atau dimiliki asing10;

4. Perusahaan besar yang mempekerjakan lebih dari 250 karyawan;

5. Perusahaan yang tidak ditugaskan: perusahaan yang aktif dalam jasa keuangan, layanan pemerintah, pendidikan atau perawatan kesehatan tidak ditetapkan ke kelas ukuran tertentu.

Secara keseluruhan, ada 640 kemungkinan kombinasi kelas ukuran industri (128 kali 5) paling detail tingkat. Tetapi karena suatu industri dipecah menjadi kategori 1-4 atau tidak dipecah sama sekali (kategori 5), ukuran industri lebih sedikit kombinasi kelas tetap, total 459

UKM memainkan peran penting dalam perekonomian bisnis non keuangan belanda. Dimana, menghasilkan $61,8 \%$ dari nilah tambah keseluruhan lebih tinggi dari rata-rata UE sebesar 56,8\% dan menyumbang $64,2 \%$ dari keseluruhan pekerjaan sedikit lebih rendah dari rata-rata UE yang sebesar 66,3. UKM Belanda memperkerjakan rata-rata 3,2 orang, lebih rendah dari rata-rata 3,9 untuk UE secara keseluruhan. UKM dalam perdagangan grosir dan enceran menyumbang lebih dari seperempat dari 
nilai tambah UKM secara keseluruhan, sebesar 27,4\%, di atas rata-rata UE yang sebesar $21,8 \%$.

\section{a. Aspek Hukum UMKM Belanda}

Prinsip 'Think Small First' sangat diperlukan, yang dimaksud sebagai prinsip paduan untuk semua kegiatan pembuatan kebijakan dan hukum. Para pembuat kebijakan harus mempertimpangkan kepentingan UKM pada tahap awal proses pembuatan kebijakan. Prinsip kebijakan tersebut menyerukan agar undang-undang yang baru dirancang, aturan, dan prosedur administratif dibuat dan mudah diterapkan. Sejak 2008, sejumlah besar tindakan telah dilakukan berdasarkan prinsip 'Think Small First'. Para pemangku kepentingan UKM berharap pembahasan kebijakan yang masih berlangsung dalam pemerintahan baru akan mengarah pada inisiatif kebijakan baru yang meningkatkan posisi UKM di Belanda. Pada tahun 2011, Kementerian Perekonomian meluncurkan 'Program beban administrasi 2011-2015 (Programma Regeldruk Bedrijven 2011-2015) dengan langkah-langkah tentang upah, pajak, usaha baru dan perizinan. Program ini mengurangi biaya administrasi untuk UKM antara 5-10\% antara tahun 2011-2015. ${ }^{28}$

Selama periode tersebut, dua langkah kebijakan diterapkan atas prinsip SBA (Small Busniness Act) ini. Pada bulan januari 2017, program faktur elektronik (elektronisch factureren) diterapkan di tingkat negara bagian pusat untuk mengurangi beban administrasi dan memastikan lebih sedikit kesalahan yang dibuat dalam setoran elektronik. Program yang sama menyusul di tingkat pemerintah daerah pada tahun 2019. Mulai tahun anggaran 2016, badan hukum yang tergolong mikro atau kecil wajib menyampaikan laporan keuangannya dengan menggunakan SBR (standard business report) atau layanan online Dutch Chamber of

28 Deloitte, Dutch Digital Infrastructure, at https://www.dinl.nl/wpcontent/uploads/2016/11/17112016-Dutch-Digital-Infrastructure-Report-2016.pdf, Tahun 2016, Diakses 07 Desember 2020, hal.18. 
Commerce $(\mathrm{KVK}){ }^{29}$ Langkah tersebut mulai diterapkan badan hukum dikelas bisnis menengah 1 tahun kemudian. Sejak tahun 2017, wajib melaporkan menggunakan salah satu metode di atas.

Pada tahun 2017, Independent Review Collage for Regulatory Burden (Onafhankelijk Regeldruk Toestsingscollage) didirikan untuk membantu semua departemen pemerintah pusat mempersiapkan undangundang dengan berbagai pengetahuan dan keahlian praktis. Tujuannya adalah untuk mencapai pemetaan yang lebih baik dari dampak beban regulasi terhadap manfaat ekonomi dan sosial. ${ }^{30}$ Pada 2015, Kementerian urusan ekonomi meluncurkan starup delta, sebuah sistem yang menghubungkan lebih dari 10 pusat inovasi teknologi Belanda di seluruh negeri dengan beberapa pusat inovasi teknologi Belanda diseluruh negeri dengan beberapa pusat internasional. Ini memberikan dukungan bisnis muda di Belanda dan asing serta memungkinkan bisnis yang mudah mapan untuk berkontribusi pada pertumbuhan lanjut

Pada tahun 2016, pemerintah Belanda memperkenalkan undangundang baru untuk melindungi hak pension orang yang bekerja memulai bisnis mereka sendiri. Undang-Undang ini secara khusus dirancang untuk menjamin kelangsungan dan pertumbuhan pensiunn bagi wiraswasra untuk memulai bisnis saat bekerja atau meninggalkan pekerjaan mereka. Undang-undang tentang Pelepasan Tunjangan Hidup dan Pendapatan Pekerjaan, dan Promosi Kelanjutan Sukarela Pembangunan Pensiun (wet vrijlating lifrenteopbouw en inkomsten uit arbeid en bervordering vrijwillige voorttzetting pensioenopbouw) memungkin karyawan untuk secara sukarela melanjutkan pensiun mereka saat ini jika aturan pensiun

\footnotetext{
29 KvK-Bedrijvendynamiek, Jaaroverzicht 2017, available at https://www.kvk.nl/download/Bedrijvendynamiek\%202017Q4 \%20definitief_tcm109-453456.pdf, last accessed 07 December 2020.

${ }^{30}$ A.J. Bernard Jensen A., J. S. Jensen, P.Schoot, Redding, Schott. Firms in international trade. The Journal ofEconomic Perspectives Tahun 2007, hal. 105-130.
} 
mereka memungkinkan untuk kelanjutan seperti.${ }^{31}$ Undang-undang baru memperpanjang periode di mana anggota dapat memilih kelanjutan dari 3 bulan menjadi 9 bulan.

Sejak 2008, kemajuan Belanda dalam bantuan \& pengadaan publik relatif lemah, dengan tindakan lebih lanjut diperlukan untuk mengembangkan bidang ini. Namun demikian, sejumlah tindakan telah dilakukan selama beberapa tahun terakhir. Undang-undang Pengadaan Publik tahun 2012 (aanbestedingswet 2012) meningkatkan akses UKM ke pelelangan umum. Amandemen yang menerapkan arahan pengadaan UE terbaru mulai berlaku pada 1 Juli 2016. Pada 2013, Belanda menciptakan kemungkinan bagi UKM dan pekerja lepas untuk mengajukan penawaran yang dikeluarkan oleh pemerintah. Juga mempersiapkan platform web yang disebut TenderNed, yang juga memberikan visibilitas yang lebih baik untuk pemerintah.

Menurut 'Act on the Role of the Dutch State on the Private Market' (Wet Mark en overhead),kegiatan ekonomi oleh otoritas public dibatasi dan tunduk pada kondisi tertentu. Perusahaan swasta dapat mengajukan pengaduan jika mengalami persaingan tidak sehat. Undang-undang ini diperkenalkan pada 2012 dengan tanggal kedaluwarsa pada 2017 tetapi telah diperpanjang. Pemerintah menempatkan Pusat Keahlian Pengadaan Publik Belanda, PIANOo, untuk memprofesionalkan pengadaan dan tender di semua departemen pemerintah, meningkatkan efisiensi petugas pengadaan pemerintah dan memastikan kepatuhan yang lebih baik terhadap peraturan. PIANOo menyatukan para ahli di bidang tertentu, mengumpulkan pengetahuan dan pengalaman, serta memberikan saran. Ini juga mendorong dialog antara otoritas kontraktor pemerintah dan perusahaan sektor swasta.

\section{b. Kondisi UMKM Belanda}

\footnotetext{
${ }^{31} \mathrm{CBS}$, Trends In The Netherlands, available at https://www.cbs.nl/ /media/_pdf/2017/44/trends_in_the_netherlands_2017_web.pdf,2017, last accessed 07 Desember 2020 .
} 
Belanda mempertahankan skor yang sejalan dengan rata-rata UE untuk akses keuangan, meskipun kemajuannya secara keseluruhan sejak 2008 cukup kuat. Sementara biaya pinjaman untuk pinjaman kecil dibandingkan dengan yang besar adalah yang ketiga tertinggi di UE (meskipun turun sedikit sejak 2016), Belanda memiliki lingkungan terkuat di Negara Anggota untuk pendanaan ekuitas, pendanaan 'malaikat bisnis' profesional dan pemberi pinjaman swasta pendanaan, semuanya meningkat antara tahun 2016 dan $2017 .{ }^{32}$ Tingkat bunga tahunan rata-rata untuk pinjaman kecil dan persentase pengajuan pinjaman yang ditolak turun sangat sedikit, meskipun peningkatan yang lebih substansial dalam akses ke dukungan keuangan publik terlihat jelas (5,9\% menunjukkan penurunan pada tahun 2017 terhadap 11,5\% pada tahun 2016) dan kesediaan bank untuk memberikan pinjaman (13,9\% menunjukkan penurunan pada tahun 2017 dibandingkan 18,8\% pada tahun 2016). Kerugian piutang tak tertagih sebagai persentase dari total omset turun dari 2,6\% pada 2016 menjadi 2,1\% pada 2017, membawa angka di bawah level 2008 sebesar $2,4 \%$ untuk pertama kalinya. ${ }^{33}$

Sejak 2008, beberapa alat untuk menarik modal ventura diluncurkan dan diskusi kebijakan untuk meningkatkan akses keuangan bagi UKM masih terus berlangsung. Pada tahun 2013, pemerintah berupaya meningkatkan akses pembiayaan UKM dengan meningkatkan ketersediaan risiko permodalan. Sejak 2015, 'Qredits' telah memberikan kredit mikro hingga EUR 250.000, terutama di sektor perhotelan, ritel, dan layanan bisnis. Qredits telah membantu lebih dari 12.000 wirausahawan pemula dalam pembiayaan mereka dan organisasi menyediakan pembinaan bagi wirausahawan dengan lebih dari 650 Pembina.

Selama periode referensi, kemajuan lebih lanjut dicapai pada prinsip SBA ini dengan peluncuran empat inisiatif baru. 'BMKB' (Borgstellingskrediet MKB) harus mengatasi tingginya persentase

${ }^{32}$ European Commission, 2018 SBA Fact Sheet Netherlands, hal.13.

${ }^{33}$ Lemmers, O. The share of SMEs in trade and investments; three delineations of SMEs. Statistics Netherlands, ( Dutch:2014), hal. 100. 
penolakan pinjaman usaha untuk UKM oleh bank. BMKB akan terbuka untuk bank maupun non bank hingga tahun 2021, setelah itu akan dievaluasi. Membuka fasilitas untuk non-bank akan membantu UKM mendapatkan kredit dengan memperluas kelompok pemberi pinjaman potensial. Pemerintah Belanda juga telah membentuk dana beban subordinasi sebagai bagian dari rencana tindakan tambahan untuk memperluas cakupan modal risiko yang tersedia untuk UKM.

Dana tersebut memberikan modal tambahan untuk investasi malaikat bisnis dan jaminan pinjaman untuk pendanaan awal. 'Scale-up Fund' dirancang untuk membantu perusahaan muda yang menjanjikan mendapatkan akses yang lebih mudah ke keuangan, di luar saluran modal ventura biasa. Tujuannya adalah untuk memungkinkan perusahaan rintisan yang tumbuh cepat untuk memperluas aktivitas mereka secara signifikan inovasi dan pertumbuhan ekonomi yang mereka kontribusikan ke Belanda.

Sebuah putaran konsultasi telah disiapkan untuk menilai tingkat dukungan untuk 'Invest-NL', yang dimaksudkan untuk menjadi bank promosi nasional baru yang beroperasi sebagai entitas swasta bersama dengan bank reguler dan dana pensiun, dengan negara sebagai pemegang saham tunggal dan Pengelola Keuangan. Invest-NL sedianya akan mulai beroperasi pada 1 Januari 2019. Namun, ini telah ditunda setidaknya selama 1 tahun. Invest-NL diharapkan memiliki total kapitalisasi EUR 2,5 miliar dan juga akan berfungsi sebagai titik kontak tunggal untuk modal ventura, jaminan, asuransi kredit ekspor, dan program pendanaan internasional / UE yang digunakan oleh para pengusaha. ${ }^{34}$

Belanda terus menunjukkan kinerja di atas rata-rata UE di bidang ini, dengan kemajuan yang stabil sejak tahun 2008. Belanda memiliki fondasi sains dan teknologi yang sangat kokoh yang menopang UKM-nya, dengan tingkat transfer teknologi tertinggi dari akademisi ke perusahaan baru dan yang sedang berkembang. Ini juga memiliki skor tertinggi pada

\footnotetext{
${ }^{34}$ European Commission, Op.Cit, hal.12.
} 
dukungan untuk sains dan teknologi basis usaha yang berfokus pada teknologi kelas dunia, pada dukungan yang tersedia bagi para insinyur dan ilmuwan untuk komersialisasi ide mereka dan pada kecukupan subsidi pemerintah untuk akuisisi teknologi di perusahaan baru dan berkembang . Hampir semua area ini mengalami pertumbuhan antara tahun 2016 dan 2017. ${ }^{35}$ Sementara persentase karyawan dengan keterampilan TI spesialis dan proporsi UKM yang memberikan pelatihan semacam ini kepada karyawan mereka meningkat dibandingkan angka tahun 2016 (dari 24,5\% menjadi $25 \%$ dan dari 20,7\% masing-masing menjadi 21,9\%), proporsi UKM yang menjual secara online sedikit turun dari $16,1 \%$ pada tahun 2016 menjadi 15,3\% pada tahun 2017, level terendah ketiga sejak tahun 2008. Proporsi UKM yang membeli secara online dan total omset dari eniaga keduanya tumbuh sedikit tetapi tetap di bawah level 2008.

\section{c. Hasil Empiris UMKM}

Bagian ini menggambarkan perbedaan peran UKM dan perusahaan besar dalam perekonomian Belanda. Pertama itu menunjukkan distribusi nilai tambah yang dihasilkan oleh UKM dan perusahaan besar di atas industri. Kemudian kami menyajikan hasil dari beberapa analisis inputoutput dasar yang diperoleh dengan menggunakan yang baru mengembangkan IOT diperpanjang. Selain memperkirakan impor yang terkandung dalam ekspor, tabel ini juga menunjukkan peran dari dua kelas ukuran sebagai pemasok untuk permintaan menengah dan akhir, dan keterlibatan mereka di rantai nilai global (bagian Belanda). Dalam bagian ini perusahaan dianggap UKM jika grup perusahaannya di bawah kendali Belanda dan mempekerjakan kurang dari 250 orang. ${ }^{36}$

Kontribusi UKM terhadap perekonomian Belanda

\footnotetext{
${ }^{35}$ European Commission, Op.Cit, hal.13.

36 Stephen Chon and Friends, The role of Small and medium-sized enterprises in the dutch economy: An analysing using an extended supply and use table, August 2018, hal. 11.
} 
Meskipun total nilai tambah oleh UKM sebanding dengan total nilai tambah oleh perusahaan besar, bahwa ada perbedaan besar antara distribusi nilai tambah industri. UKM relatif besar dalam hal nilai tambah di bidang pertanian, konstruksi, perdagangan dan jasa. Pertambangan dan manufaktur didominasi oleh perusahaan besar sehingga pedagang grosir dapat dengan mudah beroperasi dengan kurang dari 250 karyawan, sedangkan petrokimia industri, misalnya, hampir seluruhnya terdiri dari perusahaanperusahaan besar nilai tambah dari industri tersebut. Ini adalah temuan yang langsung dan intuitif.

Komposisi input yang berbeda untuk UKM dan perusahaan besar Selain itu perbedaan antara UKM dan perusahaan besar dalam hal industrinya juga ada perbedaan dalam struktur masukan. Berdasarkan perhitungan, menunjukkan bahwa UKM tidak terlalu bergantung pada impor dalam produksi barang dan jasa untuk permintaan akhir daripada perusahaan besar. Rata-rata, UKM membutuhkan 19 sen impor untuk menghasilkan 1 euro dari permintaan akhir, sedangkan permintaan besar perusahaan membutuhkan 41 sen.

\section{PENUTUP}

\section{A. Kesimpulan}

1. Di negara Belanda, orang mula-mula mendirikan koperasi konsumsi untuk menyediakan keperluan sehari-hari. Tetapi kemudian meluas dan muncul beberapa jenis atau nama koperasi. Di Rotterdam pada tahun 1860, persatuan buruh, Nederlandsch Werkman, mendirikan perkumpulan toko. Tetapi karena modalnya kecil, tempat tinggal buruh relatif tersebar, dan anggota kurang, perhatian dan kurang partisipasi pada toko akhirnya toko itu pun tidak dapat berkembang. Hal yang sama juga berlaku pada buruh di Amsterdam, yang pada tahun 1866, dibawah pimpinan N.G. Pierson mendirikan perkumpulan toko. Tidak kurang dari 2000 buruh menyatakan bersedia menjadi anggota. Tetapi pada waktu 
toko dibuka, jarang orang datang untuk melakukan pembelian. Dan akhirnya pada penghujung akhir tahun 1866 dibubarkan. Kita dapat melihat bahwa negara maju seperti Belanda masih mengandalkan koperasi untuk menyejahterakan masyarakatnya agar negaranya tetap maju. Sudah banyak negara berkembang yang juga akhirnya berhasil dalam menjalankan koperasi untuk mendorong pertumbuhan ekonomi masyarakat. Karena kesejahteraan seluruh rakyat, suatu bangsa akan hidup tentram dan adil serta tidak ada lagi kesenjangan sosial. Pengaturan lain yang memberikan kemudahan terakhir yang dapat ditemukan adalah pengaturan prinsip keterbukaan keanggotaan koperasi. Masuk dan keluarnya anggota cukup dibuktikan oleh pencatatan di dalam daftar. Dengan demikian, tidak lagi diperlukan adanya pihak ketiga, dan tidak pula pejabat maupun notaris yang membuat surat resmi sebagai anggota. Akses masyarakat untuk berperan serta dalam membangun koperasi menjadi semakin terbuka dan semakin mudah. Kemudahan lain diberikan sebagai tindak lanjut dari pengaturan tersebut Cooperatie Dienst (Jawatan Koperasi) pada tahun 1930 di bawah Department van Binnenlandshe Bestuur (Departemen Dalam Negeri) dan pada Tahun 1932 menerbitkan Surat Keputusan Pemerintah Nomor 29 yang dimuat dalam Staatsablad Nomor 634 Tahun 1932, yang menetapkan bahwa koperasi yang dibentuk berdasarkan Staatsblad Tahun 1927 Nomor 91, bebas pajak selama 10 tahun semenjak didirikan.

2. Aspek UKM merupakan Domain kebijakan untuk UKM sangatlah kompleks, dengan kompleksitas ini yang berasal dari beragam UKM (baik dari segi ukuran maupun aktivitas) dan dari banyak faktor yang memengaruhi kinerja UKM. Jawaban pemerintah Belanda untuk kompleksitas ini adalah rencana komprehensif yang membahas sub-segmen sektor UKM, mencatat dan mengklasifikasikan apa yang paling penting bagi UKM di setiap 
sub-segmen. Hanya dengan rencana yang tidak terpisahkan dimungkinkan untuk membangun strategi untuk mendongkrak kinerja UKM.

Sekretaris Negara Belanda yang baru dari Kementerian Urusan Ekonomi dan Kebijakan Iklim mengumumkan peluncuran rencana integral untuk sektor UKM Belanda ('MKB Actieplan') yang akan datang. Rencana tersebut menetapkan kelanjutan dan peningkatan bauran kebijakan yang ada yang menargetkan UKM, seperti kebijakan start-up dan kebijakan yang membantu membangun bisnis masa depan melalui $R \& D$ dan inovasi. Rencana tersebut juga menambahkan strategi yang koheren yang menargetkan peningkatan produktivitas dengan menyebarkan pengetahuan dan praktik terbaik secara lebih efektif (khususnya dalam digitalisasi), memodernisasi peraturan, dan meningkatkan akses ke modal dan keterampilan. Rencana aksi UKM diterbitkan pada 29 Juni 2018.

Direktorat Jenderal Eropa untuk Pasar Internal, Industri, Kewirausahaan dan UKM (DG GROW) membuat lembar fakta SBA sebagai bagian dari Tinjauan Kinerja UKM (SPR), kendaraan utamanya untuk analisis ekonomi masalah UKM. Mereka menggabungkan informasi statistik dan kebijakan terbaru yang tersedia. Diproduksi setiap tahun, mereka membantu mengatur informasi yang tersedia untuk memfasilitasi penilaian kebijakan UKM dan memantau implementasi SBA. Mereka mencatat dan mencatat kemajuan. Itu bukan penilaian kebijakan Negara Anggota. Sebaliknya, mereka harus dianggap sebagai sumber informasi tambahan untuk meningkatkan pembuatan kebijakan berbasis bukti. Misalnya, mereka hanya mengutip langkah-langkah kebijakan yang dianggap relevan oleh pakar kebijakan UKM nasional. Mereka tidak dan tidak dapat mencerminkan semua tindakan yang telah diambil pemerintah selama periode referensi. 
Ada lebih banyak informasi kebijakan pada database yang dapat diakses dari situs web SPR.

\section{B. Saran}

1. Dalam pembangunan koperasi untuk percepetan ekonomi, diperlukan kemitraan dalam bentuk partisipasi dari semua unsur yang terkait untuk pengembangan koperasi. Melalui konsep mekanisme kerjasama atau keterkaitan dengan perusahaan besar dalam bentuk kemitraan usaha.

2. Manajemen koperasi harus menjalankan fungsi-fungsi manajamen agaer perusahaan koperasi dapat berjalan secara efesien dan efektif dalam memenugi tujuan promosi anggota.

3. Bagi UMKM, usaha yang dijalankan berbekal dengan modal sendiri atau asupan dari pihak luar sekiranya dapat difokuskan untuk pengembangan usaha terutama produk dan perspektif lain seperti pembiayaan, pemasara, kemitraan dan wawasan akan perkembangan pasar sehingga dapat berkembang dari hari ke hari dan tetap menjadi penyangga perekonomian negara Belanda.

\section{DAFTAR PUSTAKA}

\section{Buku}

Arifin, Sitio dan Halomoan,Tamba. Koperasi, Teori dan Praktik. (Jakarta: Erlangga, 2001).

Arsyad, Lincolyn. Ekonomi Pembangun.(Yogyakarta: STIE YKPN, 2008).

Firdaus, Muhammad dan Susanto, Edhi, Agus. Perkoperasian Sejarah, Teori dan Praktek. (Bogor: Ghalia Indonesia, 2004).

Hamid, Suandi, Edy. Perekonomian Indonesia.(Jakarta: Pusat Penertbitan Universitas Terbuka, 2006).

Marzuki , Mahmud, Peter. Penelitian Hukum. (Jakarta: Kencana Prenada Media Group, 2005). 
Nisrina Farah, dkk. Cooperatives in West, Socialist, and Developing Countries, (Bandung: Universitas Komputer Indonesia, 2016).

O. Lemmers. The share of SMEs in trade and investments; three delineations of SMEs.Statistics Netherlands. ( Dutch:2014).

Prasetya, Ansika. Sejarah Perkembangan Koperasi Di Indonesia. Tanggal 11 Desember 2013.

Priharto, Sugi. Pengertian Koperasi. 2 Agustus 2019.

Subandi. Ekonomi Koperasi. (Bandung: Alfabeta, 2014).

Sularso dan Damanik. Peraturan Perundang-undangan Koperasi di Indonesia. (Jakarta: Dwi Segara, 1982).

\section{Jurnal}

Bernard Jensen, A.J.,dan S. Jensen, P.Schoot, Redding, Schott. Firms in international trade. The Journal of Economic Perspectives Tahun 2007.

Chon Stephen and Friends. The role of Small and medium-sized enterprises in the dutch economy: An analysing using an extended supply and use table.Statistics Netherlands . Agustus 2018.

European Commission, 2018 SBA Fact Sheet Netherlands.

Hudiyanto, Koperasi: Ideologi dan Pengelolaannya, Proyek Peningkatan Penelitian Pendidikan Tinggi Direktorat Jenderal Pendidikan Tinggi Departemen Pendidikan Nasional.

Nauwelaerts, Ysabel dan Hollaender, Iris. Innovation Management of SMEs in The CreativeSector in Flanders and The Netherlands. Vol.6,Iss.3.

Sofiana, Trian. Konstruksi Norma Hukum Koperasi Syariah Dalam Kerangka Sistem Hukum Koperasi Nasional. Jurnal Hukum Islam (JHI).

\section{Artikel}

CBS. Trends In The Netherlands, available at https://www.cbs.nl/ /media/_pdf/2017/44/trends_in_the_netherlands_2017_web.pdf,2017, diakses 07 Desember 2020. 
Deloitte, Dutch Digital Infrastructure. at https://www.dinl.nl/wpcontent/uploads/2016/11/17112016-Dutch-Digital-Infrastructure-Report2016.pdf. Tahun 2016, Diakses 07 Desember 2020.

European Commission. What is an SME? diakses 07 December 2020 at http://ec.europa.eu/growth/smes/business-friendly-environment/smedefinition_en.

Intercompany Solutions. Daftarkan Asosiasi Di Belanda. 13 April 2018.

Intercompany Solutions. Membentuk Koperasi Di Belanda. 15 April 2018.

KvK-Bedrijvendynamiek. Jaaroverzicht $2017 . \quad$ available at https://www.kvk.nl/download/Bedrijvendynamiek\%202017Q4 \%20definitief_tcm109-453456.pdf. diakses 07 December 2020.

Prasetya Ansika. Sejarah Perkembangan Koperasi Di Indonesia. Tanggal 11 Desember 2013.

Uang Teman. Pengertian Koperasi Menurut Para Ahli Dan Lembaga Penelitian. 30 Agustus 2017.

Wikipedia Bahasa Indonesia. Koperasi. https://id.wikipedia.org/wiki/Koperasi. 